Transportation Research Forum

Book Review (1): Urban Sprawl and Public Health: Designing, Planning, and Building for Healthy Communities

Book Review (2): Health and Community Design: The Impact of the Built Environment on Physical Activity

Book Author(s) (1): Howard Frumkin, Lawrence Frank, and Richard Jackson

Book Author(s) (2): Lawrence D. Frank, Peter O. Engelke and Thomas L. Schmid

Review Author(s): John W. Baer and Mary B. Baer

Source: Journal of the Transportation Research Forum, Vol. 44, No. 2 (Summer 2005), p. 143

Published by: Transportation Research Forum

Stable URL: http://www.trforum.org/journal

The Transportation Research Forum, founded in 1958, is an independent, nonprofit organization of transportation professionals who conduct, use, and benefit from research. Its purpose is to provide an impartial meeting ground for carriers, shippers, government officials, consultants, university researchers, suppliers, and others seeking exchange of information and ideas related to both passenger and freight transportation. More information on the Transportation Research Forum can be found on the Web at www.trforum.org. 
Frumkin, Howard, Frank, Lawrence, and Jackson, Richard. Urban Sprawl and Public Health: Designing, Planning, and Building for Healthy Communities. Washington, D.C.: Island Press, 2004. ISBN 1-55963-305-0.

Frank, Lawrence D., Engelke, Peter O., and Schmid, Thomas L. Health and Community Design: The Impact of the Built Environment on Physical Activity. Washington, D.C.: Island Press, 2003. ISBN 1-55963-917-2.

\title{
URBAN SPRAWL AND PUBLIC HEALTH AND HEALTH AND COMMUNITY DESIGN
}

\author{
by John W. Baer and Mary B. Baer
}

In these two books the medical profession has provided planners with the scientific evidence that the followers of Jane Jacobs and many pedestrians, transit users, and bicyclists have intuitively known for years - that the American automobile-dependent transportation system is injuring the public's physical, mental and societal health. The suburbs have now joined the cities as unhealthy places to live - thanks to the air, water and land pollution and societal problems caused by a transportation system dependent on the automobile, its highways, and its parking lots. The pedestrian and the transit user have been elevated from minor problems for planners to groups worthy of much more solicitation and concern.

Urban Sprawl and Public Health gives the medical details on how auto, highway, and parking lot pollution affect the physical, mental, and social environment and the undesirable effects on the life styles of people, especially children. Urban Sprawl also gives an encyclopedic coverage of all the direct and indirect medical effects of sprawl on public health.

Health and Community Design describes some urban design practices and policies that could correct the ill effects resulting from our overdependence on the automobile. This book emphasizes the need for a supportive environment for walkers and how to slow traffic to speeds that are safe for pedestrians and bicyclists.
Urban Sprawl and Public Health gives many medical details on the scientific relationships between urban sprawl and pubic health problems. Two of its authors, Howard Frumkin and Richard Jackson, are medical doctors who have specialized in studying the medical effects of urban and suburban auto friendly design on the urban environment. They have researched in detail the effects on the general public of pollution caused by the automobile transportation system and its impact on urban design.

The third author, Larry Frank, is a landscape architect, transportation planner, and land-use planner who has studied how urban design has influenced travel patterns, physical activity, obesity, and pollution. He traces these public health problems to the decisions of transportation and urban planners to serve the needs and convenience of the automobile driver over the last 50 years at the expense of children, the poor, and the health of the general population.

This book is written for designers, planners, and architects interested in the physical, mental, and societal effect of their design and architecture on public health. This book also provides the medical evidence for the opinions of Jane Jacobs and her followers about the harm caused by an urban environment designed for people in cars and not for people per se. This book is also very useful for pedestrians, transit users, and bicyclists who desire a thorough rendition of 